\title{
Arbuscular Mycorrhizal Fungi Can Accelerate the Restoration of Degraded Spring Grassland in Central Asia
}

\author{
Tao Zhang, ${ }^{1}$ Yu Sun, ${ }^{2}$ Zhaoyong Shi, ${ }^{3}$ and Gu Feng ${ }^{4}$ \\ Authors are ${ }^{1}$ Doctoral Candidate, ${ }^{3}$ Associate Professor, and ${ }^{4}$ Professor, College of Resources and Environmental Sciences, China Agricultural University, \\ No. 2 Yuan Ming Yuan West Road, Haidian District, Beijing 100193, China; and ${ }^{2}$ Assistant Research Fellow, Crop Tillage and Cultivation Institute, \\ Heilongiiang Academy of Agricultural Sciences, Harbin, Heilongjiang 150030, China.
}

\begin{abstract}
Three years of field inoculation experiments were carried out in a central Asian desert to understand the effects of arbuscular mycorrhizal fungi (AMF) on the restoration process of degraded grassland. The results indicate that the biomass, density, and cover of ephemerals improved significantly after inoculation with AMF. Compared to the control treatment, aboveground biomass per plant of the mycorrhizal plant species Erodium oxyrrhynchum, Hyalea pulchella, Trigonella arcuata, and Schismus arabicus significantly increased in mycorrhizal treatment, but no significant differences were observed in the nonmycorrhizal species Alyssum linifolim and Ceratocarpus arenarius between mycorrhizal and control treatments. The total seedling numbers per square meter in the mycorrhizal treatment were much more than control treatment in all 3 yr. Inoculation with AMF increased the total cover of ephemeral plants from $7 \%$ to $14 \%$ in $2005,15 \%$ to $38 \%$ in 2006 , and $39 \%$ to $62 \%$ in 2009 than control treatment. Moreover, community productivity (shoot dry weight, grams per square meter) in mycorrhizal treatments significantly increased from 6 to 29 in 2005, 11 to 36 in 2006, and 27 to 81 in 2009 compared with the control treatment. It is concluded that AMF can speed up the regeneration process of grassland and this may be used as an effective biological approach in the restoration of degraded desert ephemeral plant communities.
\end{abstract}

\section{Resumen}

Se realizaron tres años de experimentos de inoculación de campo en un desierto de Asia central para entender los efectos del hongo micorriza arbuscular (AMF) sobre el proceso de restauración de un pastizal degradado. Los resultados indican que la biomasa, densidad y cobertura de plantas efímeras mejoraron significativamente después de la inoculación con AMF. Comparada con el control la biomasa de la cobertura vegetal por planta de la especie micoriza Erodium oxyrrhynchum, Hyalea pulchella, Trigonella arcuata y Schismus arabicus incrementó significativamente en los tratamientos con micorrizas. Sin embargo, no se observaron diferencias significativas en las especies sin micorrizas Alyssum linifolim y Ceratocarpus arenarius entre micorrizas y los tratamientos control. El número total de plántulas por metro cuadrado en el tratamiento con micorrizas fue mucho mayor que el observado en el tratamiento control durante los tres años. La inoculación con AMF incrementó la cobertura total de plantas efímeras de $7 \%$ a $14 \%$ en 2005 , de $15 \%$ a $38 \%$ en 2006 y $39 \%$ a $62 \%$ en 2009 comparado con los tratamientos control. Adicionalmente, la productividad de la comunidad (peso seco, gramos por metro cuadrado) en los tratamientos con micorrizas incrementó significativamente de 6 a 29 en 2005 de 11 a 36 en 2006, y 27 a 81 en 2009 comparado con el tratamiento control. Se concluyó que AMF puede incrementar la velocidad del proceso de regeneración de los pastizales y esto puede ser un efectivo método biológico para restauración de comunidades desérticas degradadas efímeras.

Key Words: desertification, ephemeral plants, Gurbantunggut Desert, mycorrhizae, reestablishment

\section{INTRODUCTION}

Arbuscular mycorrhizal fungi (AMF; Phylum Glomeromycota) are the most influential members of the soil microbiota, which form symbiotic relationships with the majority of higher plants (Smith and Read 2008). AMF effectively link aboveground and belowground processes and play an important role in the uptake of plant nutrients (e.g., $\mathrm{P}, \mathrm{N}, \mathrm{Cu}$, and $\mathrm{Zn}$ ) and water (Osorio and Habte 2001; van der Heijden et al. 2006).

Research was funded by grants from the Chinese National Natural Science Foundation (30770341) and the International Fund for Agricultural Development (the WATERCOPE project, I-R-1284).

Correspondence: Gu Feng, College of Resources and Environmental Sciences, China Agricultural University, No. 2 Yuan Ming Yuan West Road, Haidian District, Beijing 100193, People's Republic of China. Email: fenggu@cau.edu.cn

Manuscript received 18 January 2011; manuscript accepted 19 February 2012.
Moreover, AMF can improve the ability of host plants to resist biotic or abiotic stresses such as drought (Auge 2001), salinity (Feng et al. 2002), heavy metals (Hua et al. 2009), and pathogens (Newsham et al. 1995). In some extreme environments, some plant species cannot survive without AMF (Pennisi 2004). Because of the positive effects of AMF on plant growth and water and nutrient uptake, AMF have been applied to reestablish degraded ecosystems. Smith et al. (1998) showed that AMF increased plant cover in a roadside prairie restoration site. Richter and Stutz (2002) found that mycorrhizal inoculation benefited restoration efforts in abandoned agricultural fields in semiarid regions. Inoculation with mycorrhizae improved the development of grasses during the early stages in the restoration of mine waste (Ryszka and Turnau 2007). Bingham and Biondini (2009) reported that mycorrhizal hyphae should be taken into consideration in grassland restoration and management. To our knowledge, whether 
AMF can help to re-establish degraded grassland or not in arid areas is not well understood.

Ephemeral plant is one of most important plant floras that adapt to the arid environment (less rainfall, drought, and high temperature; Shmida et al. 1986; Mao and Zhang 1994). Ephemeral plants widely distribute in Central Asia, West Asia, North Africa, and so on (Mao and Zhang 1994). Except in Gurbantunggut Desert, there are numerous ephemerals distributed in Chihuahuan Desert (Ludwig 1989), Negev Desert (Ward 1994), Mojave (Navarro et al. 2009), and Sonoran desert (Wallace and Szarek 1981), etc. In China, the ephemerals mainly distribute in Dzungarian Basin north of Xinjiang (Mao and Zhang 1994). In early spring, ephemeral plants are dominant in the plant community and form numerous synusia, with the fresh weight of ephemerals accounting for over $60 \%$ of total community yield (Zhang 1985; Zhang and Chen 2002). Ephemerals play a key role in dune stabilization and can reduce the frequency of occurrence and intensity of sand storms (Wang et al. 2003, 2006). Furthermore, ephemeral plants supply much fodder for livestock grazing in early spring, and Gurbantunggut Desert is therefore one of the most important rangelands in spring in north Xinjiang (Zhang 2002). However, in recent years the desert ephemeral vegetation has severely degraded due to various disturbances by human activities such as livestock overgrazing, construction of highways and irrigation channels, and petroleum and gas exploration (Zhang et al. 1998; Qian et al. 2001; Wang et al. 2009). The natural restoration of disturbed vegetation of ephemerals is very slow. For example, the cover of naturally restored ephemeral vegetation in $5 \mathrm{yr}$ was only $5 \%$ in site ( $\mathrm{Li}$ and Lei 2003). Thus, biotechnology that can improve the regeneration of ephemeral plants in this area is important for ecosystem stability and the development of livestock farming.

In Gurbantunggut Desert, our early research has suggested that $89 \%$ of the desert ephemerals can form mutualisms with AMF (Shi et al. 2006). Sun et al. (2008) showed that without AMF the biomass and number of seeds produced by desert plants declined sharply. However, we have no clear understanding of the potential of mycorrhizal inoculation for the productivity and community composition of desert ephemeral plants. The purpose of this study was to understand the effects of mycorrhizal inoculation on the restoration of desert ephemeral plants. We hypothesized that inoculation with AMF in the disturbed field would improve the growth of ephemeral plants, increase biodiversity of the plant community, and speed up the restoration process of the desert ecosystem. To test our hypothesis, a series of inoculation experiments were conducted in 2005, 2006, and 2009 in Gurbantunggut Desert.

\section{METHODS}

\section{Study Area}

Gurbantunggut Desert (lat $34^{\circ} 09^{\prime}-49^{\circ} 08^{\prime} \mathrm{N}$, long $73^{\circ} 25^{\prime}-$ $96^{\circ} 24^{\prime} \mathrm{E}$ ) in Central Asia is the second largest desert and the largest fixed and semifixed desert in China, covering an area of $48800 \mathrm{~km}^{2}$. The annual average temperature ranges from $-4^{\circ} \mathrm{C}$ to $9^{\circ} \mathrm{C}$ with mean temperatures of $-20^{\circ} \mathrm{C}$ to $-15^{\circ} \mathrm{C}$ and $22^{\circ} \mathrm{C}$ to $26^{\circ} \mathrm{C}$ in January and July (Shi et al. 2007), $19.5^{\circ} \mathrm{C}$ during the growing season (from April to July), and annual evaporation exceeds $2000 \mathrm{~mm}$. Although the annual precipitation in this area is $70-150 \mathrm{~mm}$, more than $70 \%$ of the precipitation falls in the spring. In addition, there is stable accumulated snowpack about $20-\mathrm{cm}$ thick in the winter every year, and this can reach $70-130 \mathrm{~d}$. In spring, there is a perched wet sand layer (approximately $50-60 \mathrm{~cm}$ ) in the soil profile (Ji et al. 2000; Wang et al. 2006). The water and heat allocation pattern creates favorable conditions for the growth and development of ephemeral plants (Mao and Zhang 1994; Zhang and Chen 2002). The average contents of available soil phosphorus $(0.5$ $\mathrm{mol} \cdot 1^{-1} \mathrm{NaHCO}_{3}$-extractable) and soil organic matter in Gurbantunggut Desert were only $1.58 \mathrm{mg} \cdot \mathrm{kg}^{-1}$ and 1.2 $\mathrm{g} \cdot \mathrm{kg}^{-1}$, respectively; the mean soil moisture content in the topsoil (Soil profile was divided into three layers and collected in depth $0-10 \mathrm{~cm}, 10-20 \mathrm{~cm}$, and $20-30 \mathrm{~cm}$. The mean soil moisture in three layers was calculated.) in April was 2-5\%, but in May it declined sharply to $0.8-1.2 \%$ (Wang et al. 2004). Our plots were located in an enclosure for preserving a canal. The canal was constructed for delivering water. The topsoil and vegetation in this enclosure were destroyed seriously during canal construction when the subsoil was placed on the surface. There are few seeds in the subsoil because most of the seeds were distributed in the top soil (0-5 cm; Zhang et al. 2006), but seeds can drift in the enclosure from the surrounding area.

\section{Experimental Design}

We used a randomized complete block design that comprised four replicates of two treatments: inoculation (referred to as mycorrhizal treatment, $+\mathrm{M}$ ) and no inoculation (referred to as control, C). The experiments were carried out at three different experimental sites in the enclosure from 25 March to 25 May in 2005 and 2006 and 28 March to 28 May in 2009. In the first $2 \mathrm{yr}$, the experiments focused on the effects of inoculation with AMF on the total productivity, density, and cover of the desert ephemeral plant community. In addition, in order to understand the mechanisms by which AMF determine plant community composition and improve plant cover and density, we conducted a field trial in 2009. Indices related to the dynamics of community cover, density, and community composition were recorded. The species that occurred locally are shown in the supplementary materials (Table S1; Available at http://dx.doi.org/10.2111/REM-D-11-00016.s1). Six dominant ephemeral species that contributed to $85 \%$ of the total abundance of the vegetation, Erodium oxyrrhynchum, Hyalea pulchella, Trigonella arcuata, Schismus arabicus, Ceratocarpus arenarius, and Alyssum linifolim, were selected. The contribution from all of the remaining species was $15 \%$ and single species less than $2 \%$.

Experimental plots $(2 \times 2 \mathrm{~m})$ were selected each year in early spring, and $32 \mathrm{~m}^{2}$ areas were treated every year. To minimize the effects of human activities, the plots were located at least 20 $\mathrm{m}$ from the fences around the enclosures. AM fungal inoculum was supplied by digging numerous holes $(15 \mathrm{~cm}$ in depth) in the plots with a soil drill before the germination of the ephemerals. Ten grams of inoculum (containing about 200 spores) were placed in each hole and then covered with a small amount of soil. The spaces between the holes were $10 \mathrm{~cm}$, and there were 361 holes in each plot. To keep the amount of microorganism consistent across holes, the same amounts of sterilized 
Table 1. Mean mycorrhizal colonization (\%) and aboveground biomass $\left(\mathrm{g} \cdot \mathrm{plant}^{-1}\right)$ of six dominant ephemeral plant species in 2006.

\begin{tabular}{|c|c|c|c|c|}
\hline \multirow[b]{2}{*}{ Species } & \multicolumn{2}{|c|}{ Mycorrhizal colonization (\%) } & \multicolumn{2}{|c|}{ Aboveground biomass $\left(\mathrm{g} \cdot\right.$ plant $\left.^{-1}\right)$} \\
\hline & C & $+\mathrm{M}$ & C & $+\mathrm{M}$ \\
\hline Erodium oxyrrhynchum & $28.0 \pm 6.1 b^{1}$ & $52.2 \pm 5.9 \mathrm{a}$ & $0.13 \pm 0.02 b$ & $0.73 \pm 0.24 \mathrm{a}$ \\
\hline Hyalea pulchella & $33.3 \pm 5.1 b^{2}$ & $56.7 \pm 8.4 \mathrm{a}$ & $0.45 \pm 0.05 b$ & $1.54 \pm 0.38 \mathrm{a}$ \\
\hline Trigonella arcuata & $26.5 \pm 3.6 b$ & $58.9 \pm 6.2 \mathrm{a}$ & $0.06 \pm 0.01 b$ & $0.14 \pm 0.03 \mathrm{a}$ \\
\hline Schismus arabicus & $32.2 \pm 2.9 b$ & $52.2 \pm 4.8 \mathrm{a}$ & $0.02 \pm 0.01 b$ & $0.08 \pm 0.03 \mathrm{a}$ \\
\hline Alyssum linifolim & $-^{3}$ & - & - & - \\
\hline Ceratocarpus arenarius & $21.1 \pm 8.1 \mathrm{a}$ & $34.5 \pm 2.2 \mathrm{a}$ & $0.12 \pm 0.03 \mathrm{a}$ & $0.11 \pm 0.02 \mathrm{a}$ \\
\hline
\end{tabular}

${ }^{1}$ Values given are mean \pm standard error.

${ }^{2}$ Different letters in a row indicate the significant difference between control treatment $(C)$ and mycorrhizal treatment $(+\mathrm{M})$ at the $P<0.05$ level.

3 — indicates that no Alyssum linifolim was found in the plots.

mycorrhizal inoculum were placed in the control plots. We harvested the ephemerals after 2 mo of growth.

\section{AMF Inoculum}

Three AM fungal species, Glomus mosseae, Glomus etunicatum, and Glomus intradices, were used, which are dominant species in the desert (Shi et al. 2007). They were isolated from the rhizosphere soil of desert ephemeral and propagated using red clover and sorghum as host plants for 4 mo. Before use, the spore densities were counted using a dissecting microscope at $\times 30$ magnification. The fungi were mixed together in a ratio of 1:1:1. The mycorrhizal inoculum consisted of root fragments, hyphae, and spores. In control treatment, the same amount of mycorrhizal inoculum that was previously sterilized by $10 \mathrm{kGy}$ ${ }^{60} \mathrm{Co} \gamma$-rays was used.

\section{Plant Investigation and Analysis}

The cover of ephemeral plants before harvesting was estimated using a modified point-frame method (Cook and Stubbendieck 1986). A one-square grid contained 100 pins (each $10 \mathrm{~cm}$ apart) was used. Plant density was defined as the number of whole plants in one square meter. Species richness was recorded as the occurrence of the number of plant species in the quadrat. Four quadrats were measured in each plot. The plant height of dominant species within a quadrat was calculated as the average of 10 random measurements of the natural height of the species. Plant diversity index (Shannon-Wiener index, $H^{\prime}$ ) was calculated as: $H^{\prime}=-\sum\left(P_{\mathrm{i}} \ln P_{\mathrm{i}}\right) . P i$ is the relative abundance of species $\mathrm{i}$ in a sample that contains $\mathrm{n}$ species.

The proportion of mycorrhizal plants was calculated as: mycorrhizal plants $(\%)=$ total mycorrhizal plant density $\times 100 /$ total plant density. Mycorrhizal plants are referred as those that can form associate symbiont with AMF, and nonmycorrhizal plants are those that cannot be colonized by AMF.

We investigated the cover and density of ephemeral plants every 2 wk in 2009 to observe the dynamics of plant cover and density. The aboveground and belowground biomasses of all of the plants located in the plots were harvested. The plants were washed free of soil with deionized water, oven dried at $70^{\circ} \mathrm{C}$ $(48 \mathrm{~h})$, and the dry weights were recorded.

A subsample of the roots (about $0.5 \mathrm{~g}$ ) was washed free of soil and cleared in $10 \%(\mathrm{w} / \mathrm{v}) \mathrm{KOH}$ at $90^{\circ} \mathrm{C}$ in a water bath for 20-30 min and stained with Trypan blue $(0.5 \% \mathrm{w} / \mathrm{v}$; Phillips and Hayman 1970). Mycorrhizal colonization in the root systems was estimated using the method of Trouvelot et al. (1986). Mycorrhizal colonization is the intensity of mycorrhizal colonization in the root system.

\section{STATISTICAL ANALYSIS}

All data were analyzed using procedures of SPSS (version 16.0). Student's $t$ test was used to detect significant differences at the level of $P<0.05$.

\section{RESULTS}

\section{Mycorrhizal Colonization}

The mycorrhizal colonization of the four mycorrhizal species $E$. oxyrrhynchum, H. pulchella, T. arcuata, and S. arabicus and the possibly mycorrhizal species $C$. arenarius were significantly increased by inoculation with AMF compared to the control treatment in 2006 and 2009 (Tables 1 and 2). The mean colonization of the four mycorrhizal species was $40 \%$ in the mycorrhizal treatment and only $15 \%$ in the control treatment. No mycorrhizal colonization was detected in the roots of $A$. linifolim (Table 2).

\section{Plant Growth}

The heights of the four species E. oxyrrhynchum, H. pulchella, T. arcuata, and $S$. arabicus in inoculation treatment were significantly higher than in the control treatment in 2009 (Table 2). The heights of E. oxyrrbynchum and T. arcuata inoculated with AMF respectively heightened by $20 \mathrm{~cm}$ $( \pm 2.84)$ and $13.55 \mathrm{~cm}( \pm 1.52)$ compared with that in the control treatment. A. linifolim and C. arenarius showed no significant differences in height between mycorrhizal treatment and control treatments (Table 2).

Compared to the control treatment, inoculation with AMF significantly improved the aboveground biomass of the four ephemerals. The aboveground biomass of mycorrhizal species E. oxyrrhynchum, H. pulchella, and S. arabicus all increased more than twofold compared with that in control treatment in 2006 and 2009 (Tables 1 and 2). A. linifolim and C. arenarius did not show significant differences in aboveground biomass between mycorrhizal and control treatments (Tables 1 and 2). The productivity of the plant community was evidently promoted by inoculation with AMF; the total aboveground 
Table 2. Mean mycorrhizal colonization (\%), plant height $(\mathrm{cm})$, and aboveground biomass $\left(\mathrm{g} \cdot\right.$ plant $\left.^{-1}\right)$ of six dominant ephemeral plants in 2009.

\begin{tabular}{|c|c|c|c|c|c|c|}
\hline \multirow[b]{2}{*}{ Species } & \multicolumn{2}{|c|}{ Mycorrhizal colonization (\%) } & \multicolumn{2}{|c|}{ Plant height $(\mathrm{cm})$} & \multicolumn{2}{|c|}{ Aboveground biomass $\left(\mathrm{g} \cdot\right.$ plant $\left.^{-1}\right)$} \\
\hline & C & $+\mathrm{M}$ & C & $+\mathrm{M}$ & C & $+\mathrm{M}$ \\
\hline Erodium oxyrrhynchum & $14.4 \pm 8.01 b$ & $34.7 \pm 2.4 \mathrm{a}^{1}$ & $21.1 \pm 1.1 \mathrm{~b}$ & $41.1 \pm 1.7 \mathrm{a}$ & $1.02 \pm 0.15 b$ & $4.28 \pm 0.35 \mathrm{a}$ \\
\hline Hyalea pulchella & $9.3 \pm 4.01 b^{2}$ & $35.6 \pm 7.3 \mathrm{a}$ & $23.1 \pm 1.5 b$ & $34.3 \pm 1.1 \mathrm{a}$ & $1.31 \pm 0.26 b$ & $3.54 \pm 0.33 \mathrm{a}$ \\
\hline Trigonella arcuata & $28.9 \pm 4.8 b$ & $66.7 \pm 6.9 \mathrm{a}$ & $4.2 \pm 0.4 b$ & $17.8 \pm 1.2 \mathrm{a}$ & $0.17 \pm 0.02 \mathrm{a}$ & $0.30 \pm 0.05 \mathrm{a}$ \\
\hline Schismus arabicus & $6.01 \pm 2.5 b$ & $22.2 \pm 2.2 \mathrm{a}$ & $11.1 \pm 0.7 b$ & $15.6 \pm 0.8 \mathrm{a}$ & $0.19 \pm 0.02 b$ & $0.42 \pm 0.05 \mathrm{a}$ \\
\hline Alyssum linifolim & $-{ }^{3}$ & - & $16.0 \pm 0.4 \mathrm{a}$ & $19.0 \pm 1.0 \mathrm{a}$ & $0.15 \pm 0.02 \mathrm{a}$ & $0.35 \pm 0.11 \mathrm{a}$ \\
\hline Ceratocarpus arenarius & $3.3 \pm 1.9 \mathrm{a}$ & $8.9 \pm 2.9 \mathrm{a}$ & $10.4 \pm 0.4 \mathrm{a}$ & $11.1 \pm 1.1 \mathrm{a}$ & $0.83 \pm 0.11 \mathrm{a}$ & $0.55 \pm 0.15 \mathrm{a}$ \\
\hline
\end{tabular}

${ }^{1}$ Different letters in a row indicates the significant difference between control treatment $(\mathrm{C})$ and mycorrhizal treatment $(+\mathrm{M})$ at the $P<0.05$ level.

${ }^{2}$ Values given are mean \pm standard error.

3 - indicates that no mycorrhizal structure was observed.

biomass per square meter in the mycorrhizal treatment increased by $22.9 \mathrm{~g}( \pm 6.3), 25.4 \mathrm{~g}( \pm 7.6)$, and $53.8 \mathrm{~g}$ $( \pm 15.3)$ compared with the control treatment in 2005, 2006, and 2009, respectively (Fig. 1).

\section{Dynamics of Plant Density and Cover}

The plant densities per square meter in mycorrhizal treatment increased significantly by $136( \pm 22), 110( \pm 14)$, and 80 ( \pm 13 ) individuals on 18 April, 2 May, and 16 May, respectively, in 2009 (Fig. 2A) compared with the control treatment. Total ephemeral plant individuals per square meter at harvest time in mycorrhizal treatment increased by $78( \pm 9)$ and $36( \pm 8)$ individuals than the control treatment in 2005 and 2006 (Fig. 2B).

The cover of plants inoculated with AMF was higher than that in control treatment. At the initial plant growth stages, there was no significant difference between mycorrhizal and control treatments, but later significant differences were observed in 2009 (Fig. 2C). The mean cover of ephemeral plants in mycorrhizal treatment increased from $3 \% \mathrm{~m}^{-2}$ to $12 \% \mathrm{~m}^{-2}$ in $2005,8 \% \mathrm{~m}^{-2}$ to $31 \% \mathrm{~m}^{-2}$ in 2006 , and $13 \% \mathrm{~m}^{-2}$ to $30 \% \mathrm{~m}^{-2}$ in 2009 compared with control treatment (Fig. 2D). Significant differences were observed between mycorrhizal treatments and control treatments in 2005, 2006, and 2009.

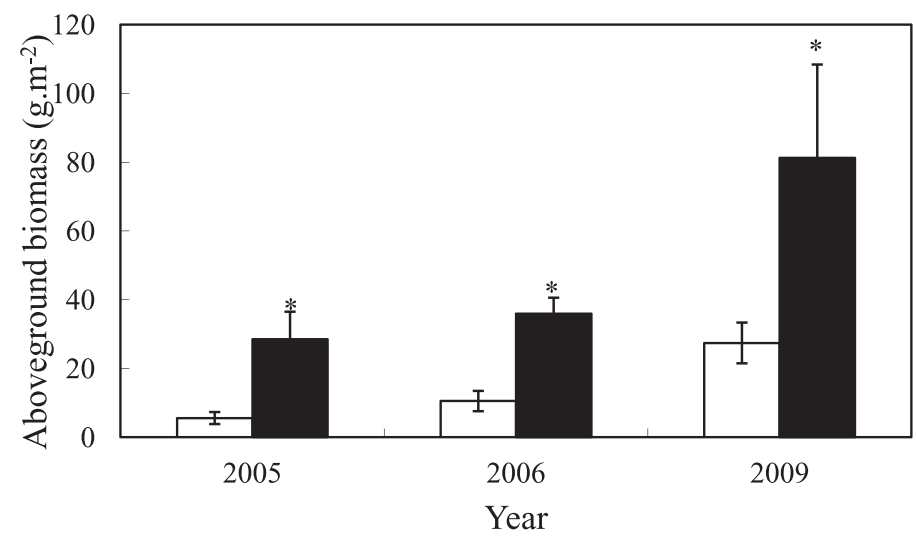

Figure 1. Productivity of the ephemeral community with and without inoculation with arbuscular mycorrhizal fungi (AMF) in 2005, 2006, and 2009. White indicates no AMF inoculation, and black indicates those inoculated with AMF. Asterisks indicate significant differences $(P<0.05)$.

\section{Effect of AMF Inoculation on Ephemeral Plant Community Composition}

Compared to control treatment, the plant diversity index $\left(H^{\prime}\right)$ in mycorrhizal treatment respectively increased by $19.5 \%$, $13.5 \%$, and $32.5 \%$ in 2005, 2006, and 2009 (Fig. 3A). The species richness of ephemerals in mycorrhizal treatment was significantly higher than in the control treatment (Fig. 3B). The community compositions were altered significantly by inoculation AMF over the $3 \mathrm{yr}$. In mycorrhizal treatments, the proportion of mycorrhizal plants in the community increased by $20 \%, 26 \%$, and $27 \%$ compared to the control treatments in 2005, 2006, and 2009, respectively (Figs. 4A-4C).

\section{DISCUSSION}

AMF are unique in terrestrial ecosystems because of their effects on improving plant $\mathrm{P}$ and water uptake (Bryla and Duniway 1997; Smith and Read 2008) and seedling support (van der Heijden 2004), which are important in the restoration of many types of vegetation. The results of $3 \mathrm{yr}$ of study support our hypothesis that inoculation with AMF accelerated the restoration process of degraded grassland in arid desert ecosystem.

A previous study found that plant growth responses to AMF ranged from positive (mutualism) to neutral (commensalism) and even to negative (parasitism; Klironomos 2003). It was found that in North American grassland community AMF improved the growth of some plant species but had no significant effects or sometimes had negative effects on the growth of other species (van der Heijden et al. 1998; Klironomos 2003). In our experiments, we observed positive effects of inoculation with AMF on the plant height and shoot biomass of four dominant mycorrhizal plants, E. oxyrrhynchum, H. pulchella, T. arcuata, and S. arabicu, but no significant effects on the plant height and shoot biomass of $A$. linifolim (Table 2) and negative effects on the aboveground biomass of $C$. arenarius. These results may be related to competition among plant species because inoculation with AMF can improve the growth of dominant mycorrhizal species, and more nutrients were absorbed by them so that the development of nonmycorrhizal species was restrained (Shi et al. 2006). In contrast, the growth improvement of mycorrhizal species may increase the number of propagules of AMF and the density of the common mycorrhizal network, for the colonization of mycorrhizal species was much higher (Tables 1 and 

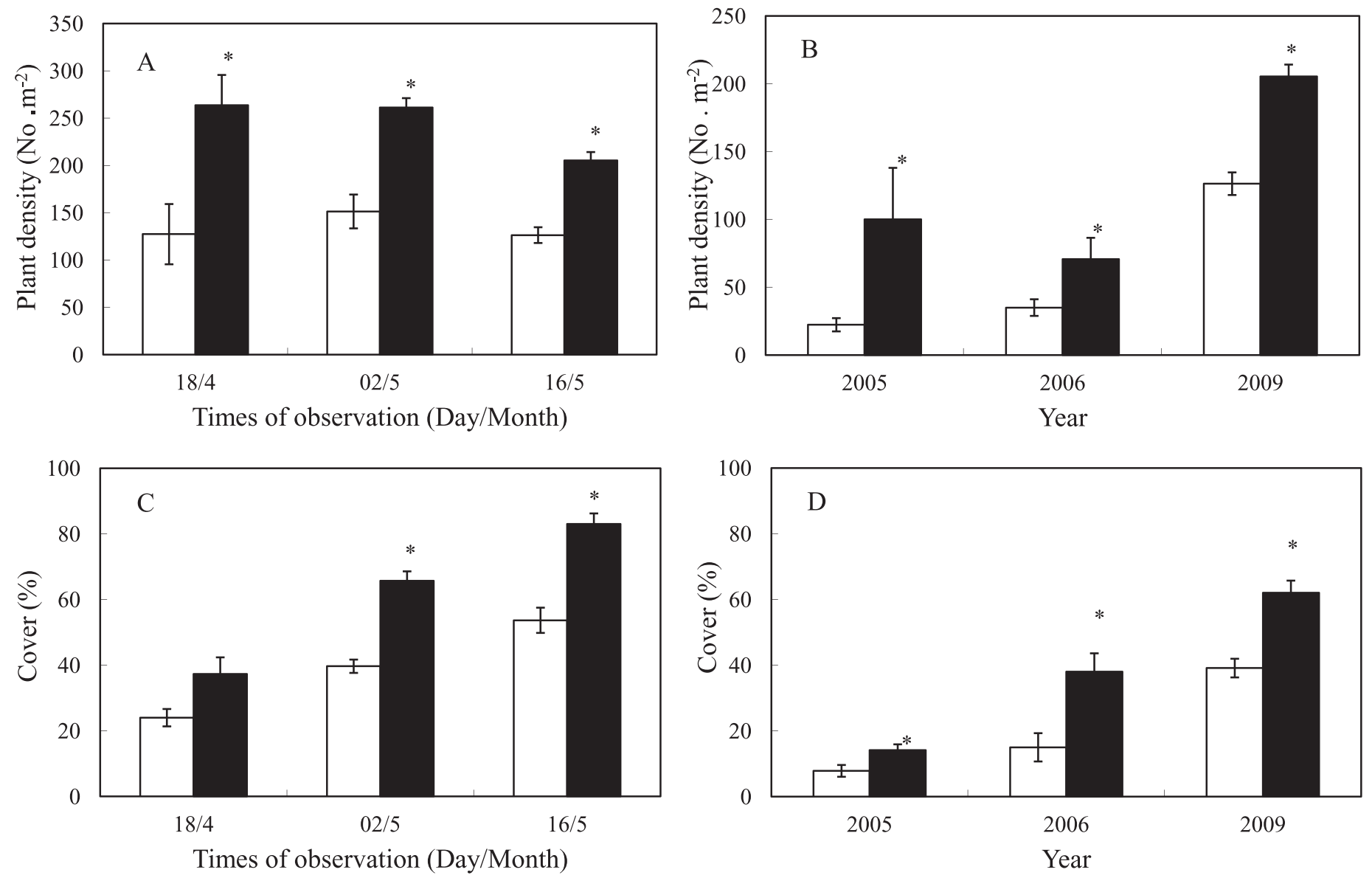

Figure 2. Dynamics of plant density (A) and cover (C) of the ephemeral community in 2009, and total density (B) and cover (D) of the ephemeral community with and without inoculation with arbuscular mycorrhizal fungi (AMF) in 2005, 2006, and 2009. White indicates those not inoculated with AMF, and black indicates those inoculated with AMF. Error bars represent the standard errors of the means. Asterisks indicate significant differences $(P<0.05)$.

2). These results indicate that the potential of AMF in the restoration ephemerals in the subsequent season might be improved.

Compared with nonmyocrrhizal plants $(A$. linifolim and $C$. arenarius), livestock prefer to eat mycorrhizal plants (E. oxyrrhynchum, H. pulchella, and T. arcuata, etc.) in Gurbantunggut Desert (Mao and Zhang 1994). The 3-yr study found

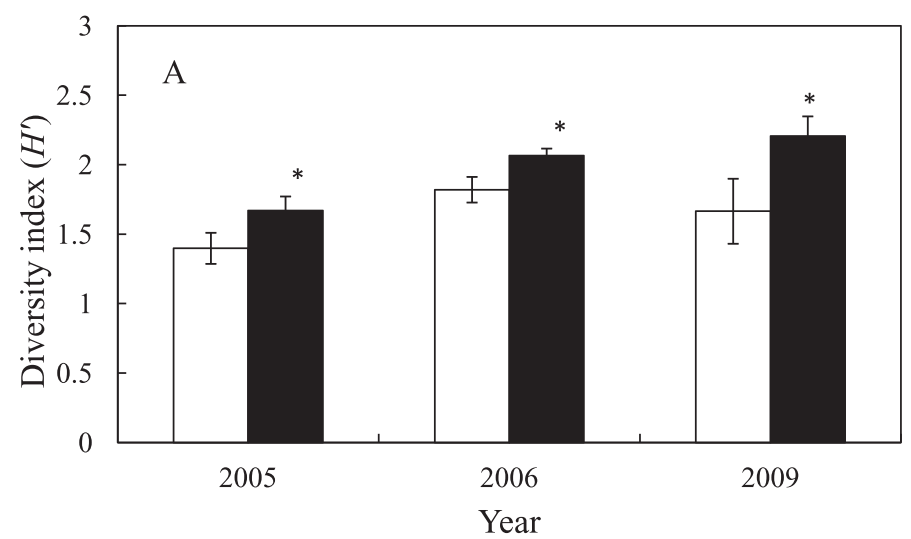

that inoculation with AMF altered the community composition, and the mean relative abundance of mycorrhizal plants increased by $23 \%$ compared with the control treatment (Fig. $4)$. It is well known that grazing in the dry season results in a decline in species richness (Enright and Miller 2007). The present study also found that inoculation with AMF significantly increased plant diversity, species richness, individual

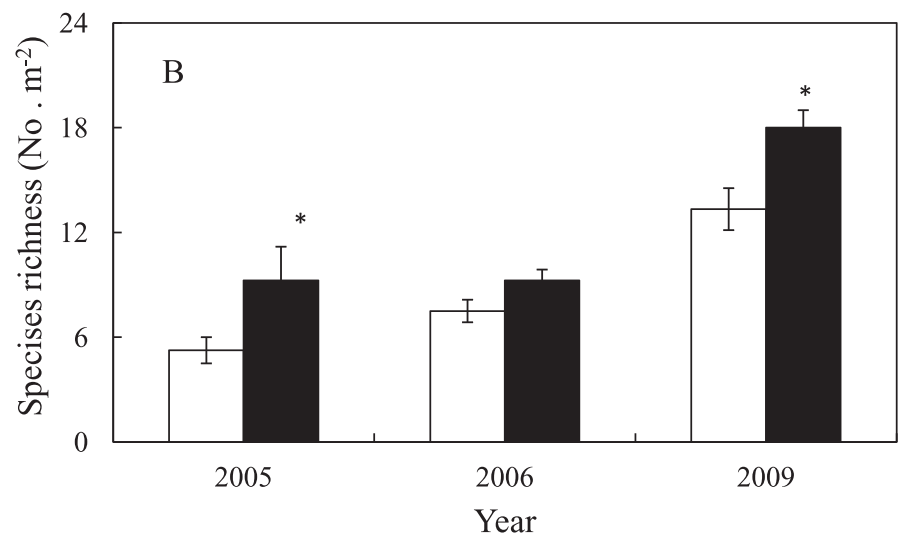

Figure 3. Plant diversity (A) and species richness (B) of the ephemeral plant community with and without inoculation with arbuscular mycorrhizal fungi (AMF) in 2005, 2006, and 2009. White indicates no AMF inoculation, and black indicates those inoculated with AMF. Error bars represent standard errors of the means. Asterisks indicate significant differences $(P<0.05)$. 

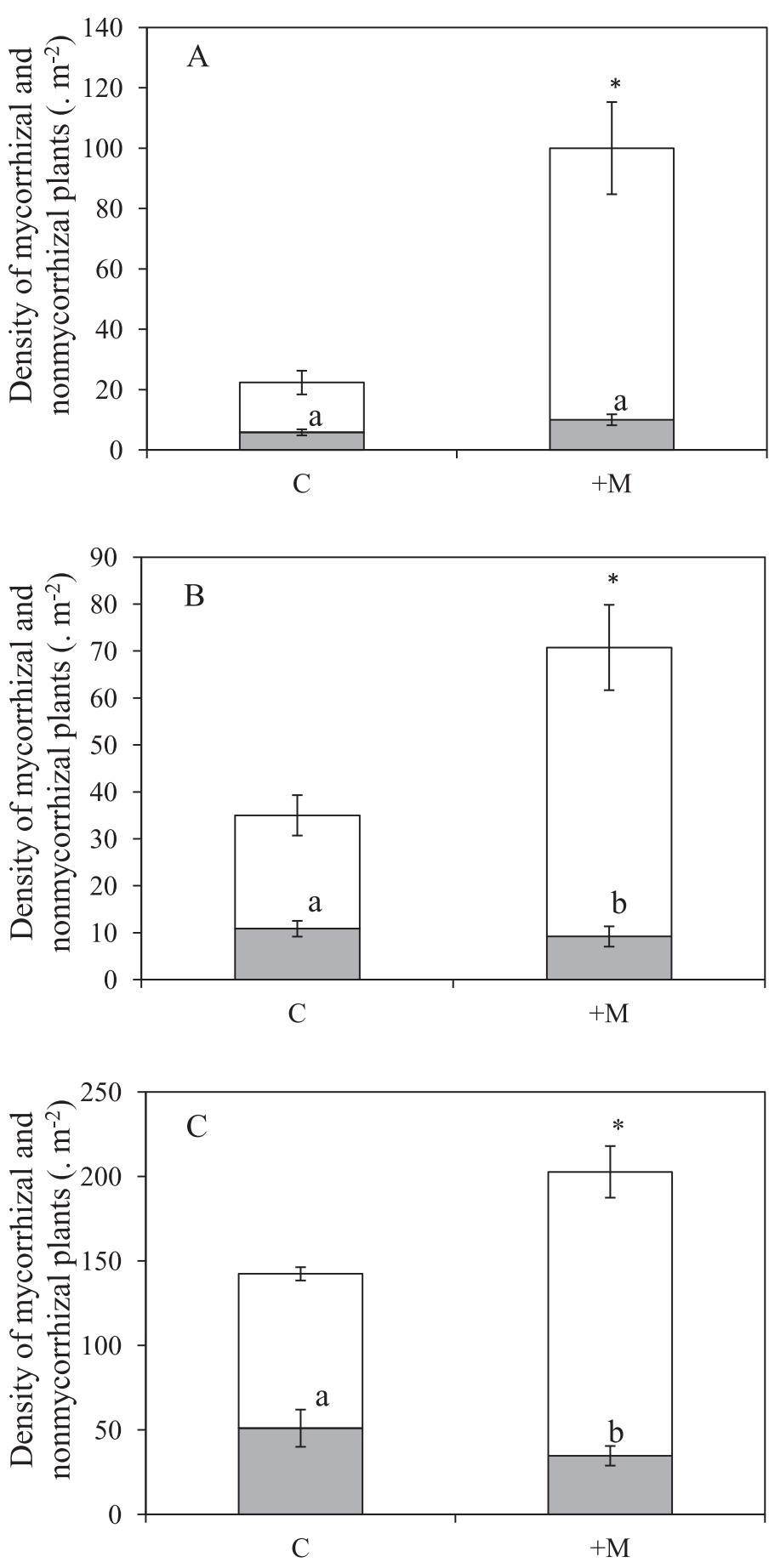

Figure 4. The proportion of mycorrhizal species (white) and nonmycorrhizal species (gray) in the ephemeral community in arbuscular mycorrhizal fungi (AMF) inoculated and control plots in 2005 (A), 2006 (B), and 2009 (C). Asterisks indicate significant differences in the proportion of mycorrhizal plants between mycorrhizal and control treatments $(P<0.05)$. Lowercase letters indicate significant differences in the proportion of nonmycorrhizal plants between mycorrhizal and control plots $(P<0.05)$.

density, and cover compared with control plots. These results suggest that AMF play a crucial role in determining community composition and maintaining plant diversity and species richness in the arid desert ecosystem.
Ephemeral plants form important pastures in early spring in Gurbantunggut Desert, but the natural re-vegetation of ephemerals is very difficult and slow in the degraded region (Li and Lei 2003). Our field results found that inoculation with AMF promoted recovery of vegetation and significantly increased the net productivity of the ephemeral community (by more than $200 \%$; Fig. 1). The results indicate that AMF accelerated the restoration process of degraded grassland. Although, application of AMF to stimulate ephemeral restoration on a large scale might be difficult due to economic cost, several strategies can be used to take advantage of the fungi in grassland restoration in arid zone. Firstly, application of AMF inoculum in severely disturbed site is sustainable as it does not have to be repeated each year (Baar 2010). Secondly, there are AM fungal propagules in the soil. Our early study has found that the spore density of the AMF was around 30 per $20 \mathrm{~mL}$ soil in undisturbed areas in Gurbantunggut Desert (Shi et al. 2007). The number of indigenous AMF propagules in the soil might be enhanced by increasing the proportion of mycorrhizal plants (Azcón-Aguilar et al. 2003). Thirdly, minimizing the disturbance and avoiding removal of the topsoil (Caravaca et al. 2005 ) is another strategy. Fourthly, seed coating techniques for mycorrhizal inoculation may be applied to accelerate restoration process on a large scale (Ortiz and Fernandez 1998).

\section{IMPLICATIONS}

AMF play a key role in plant community composition and ecosystem stability and can help to restore degraded grassland. Therefore, AMF should be taken into consideration in grassland restoration. The major conclusion from this study is that AMF can accelerate the restoration of degraded desert grassland and thereby improve plant survival, alter community composition, and increase net productivity. These results suggest that inoculation with AMF can be used as an effective biological approach in the restoration of degraded desert ephemeral plant ecosystems. The results also indicate that it is important to maintain the topsoil intact to ensure the continued presence of AMF.

\section{LITERATURE CITED}

Auge, R. M. 2001. Water relations, drought and vesicular-arbuscular mycorrhizal symbiosis. Mycorrhiza 11:3-42.

Azcón-Aguilar, C., J. Palenzuela, A. Roldan, S. Bautista, R. Vallejo, and J. M. Barea. 2003. Analysis of the mycorrhizal potential in the rhizosphere of representative plant species from desertification-threatened Mediterranean shrublands. Applied Soil Ecology 22:29-37.

BAaR, J. 2010. Restoration of plant communities in The Netherlands through the application of arbuscular mycorrhizal fungi. Symbiosis 52:87-94.

Bingham, M. A., AND M. BIondiNI. 2009. Mycorrhizal hyphal length as a function of plant community richness and composition in restored northern tallgrass prairies (USA). Rangeland Ecology \& Management 62:60-67.

Bryla, D. R., AND J. M. Duniway. 1997. Growth, phosphorus uptake, and water relations of safflower and wheat infected with an arbuscular mycorrhizal fungus. New Phytologist 136:581-590.

Caravaca, F., M. M. Alguacil, J. M. Barea, and A. Roldán. 2005. Survival of inocula and native AM fungi species associated with shrubs in a degraded Mediterranean ecosystem. Soil Biology \& Biochemistry 37:227-233. 
Cook, C. W., and J. L. Stubbendieck. 1986. Range research: basic problems and techniques. Denver, CO, USA: Society for Range Management. $317 \mathrm{p}$.

ENRIGHT, N., AND B. Miller. 2007. Livestock grazing impacts on desert vegetation, Khirthar National Park, Pakistan. Rangeland Ecology \& Management 60:680684.

Feng, G., F. S. Zhang, X. L. LI, C. Y. Tian, C. Tang, and Z. Rengel. 2002. Improved tolerance of maize plants to salt stress by arbuscular mycorrhiza is related to higher accumulation of soluble sugars in roots. Mycorrhiza 12:185-190.

HuA, J. F., X. G. Lin, R. YIN, Q. Jiang, And Y. F. ShaO. 2009. Effects of arbuscular mycorrhizal fungi inoculation on arsenic accumulation by tobacco (Nicotiana tabacum L.). Journal of Environmental Sciences-China 21:1214-1220.

JI, F., W. YE, AND W. WEl. 2000. Preliminary study on the formation causes of the fixed and semi-fixed dunes in Gurbantonggut Desert. Arid Land Geography 23:32-36.

KLIRonomos, J. N. 2003. Variation in plant response to native and exotic arbuscular mycorrhizal fungi. Ecology 84:2292-2301.

LI, S., AND J. LEI. 2003. The ecological restoration functions of the straw-checker sand-barriers, a case study along the desert highways in the Gurbantonggut Desert. Arid Zone Research 20:7-10.

LudWig, J. A., W. G. Whitford, And J. M. Cornelius. 1989. Effects of water, nitrogen, and sulfur amendments on cover, density, and size of Chihuahuan Desert ephemerals. Journal of Arid Environments 16:35-42.

Mao, Z., And D. Zhang. 1994. Conspectus of ephemeral flora in northern Xinjiang. Arid Zone Research 11:1-26.

Navarro, J. B., D. P. Moser, A. Flores, C. Ross, M. R. Rosen, H. Dong, G. Zhang, and B. P. HedLund. 2009. Bacterial succession within an ephemeral hypereutrophic Mojave Desert Playa Lake. Microbial Ecology 57:307-320.

Newsham, K. K., A. H. FitTer, And A. R. Watkinson. 1995. Arbuscular mycorrhiza protect an annual grass from root pathogenic fungi in the field. Journal of Ecology 83:991-1000.

Ortiz, R., and F. Fernandez. 1998. Effectiveness of coating pregerminated rice seed with an arbuscular mycorrhizal inoculant (ECOMIC). Cultivos Tropicales 19:1518.

OsoRIO, N. W., AND M. HABTE. 2001. Synergistic influence of an arbuscular mycorrhizal fungus and a $P$ solubilizing fungus on growth and $P$ uptake of Leucaena leucocephala in an oxisol. Arid Land Research and Management 15:263-274.

PennisI, E. 2004. The secret life of fungi. Science 304:1620-1622.

Phillips, J. M., AND D. S. HAYMAn. 1970. Improved procedures for clearing roots and staining parasitic and vesicular-arbuscular mycorrhizal fungi for rapid assessment of infection. Transactions of the British Mycological Society $55: 158-161$.

Qian, Y., L. Zhang, and Z. Wu. 2001. Destruction and regeneration of the desert vegetation in the engineering activities in the Gurbantunggut Desert. Arid Zone Research 18:47-51.

Richter, B. S., AND J. C. Stutz. 2002. Mycorrhizal inoculation of big sacaton: implications for grassland restoration of abandoned agricultural fields. Restoration Ecology 10:607-616.

Ryszka, P., and K. Turnau. 2007. Arbuscular mycorrhiza of introduced and native grasses colonizing zinc wastes: implications for restoration practices. Plant and Soil 298:219-229.

Shi, Z. Y., G. Feng, P. Christie, and X. L. Li. 2006. Arbuscular mycorrhizal status of spring ephemerals in the desert ecosystem of Junggar Basin, China. Mycorrhiza 16:269-275.

Shi, Z. Y., L. Y. Zhang, X. L. Li, G. Feng, C. Y. Tian, and P. Christie. 2007. Diversity of arbuscular mycorrhizal fungi associated with desert ephemerals in plant communities of Junggar Basin, northwest China. Applied Soil Ecology 35: $10-20$.
Shimid, A., M. Evenari, and I. Noy-MelR. 1986. Hot desert ecosystems: an integrated view. Ecosystems of the World 12:379-387.

Smith, M. R., I. Charvat, and R. L. Jacobson. 1998. Arbuscular mycorrhizae promote establishment of prairie species in a tallgrass prairie restoration. Canadian Journal of Botany 76:1947-1954.

Smith, S. E., and D. J. Read. 2008. Mycorrhizal symbiosis. 3rd ed. San Diego, CA, USA: Academic Press. p. 27.

Sun, Y., X. L. LI, AND G. Feng. 2008. Effect of arbuscular mycorrhizal colonization on ecological functional traits of ephemerals in the Gurbantonggut desert. Symbiosis 46:121-127.

Trouvelot, A., J. L. Kough, and V. Gianinazzi-Pearson. 1986. Mesure du taux de mycorhization VA d'un systeme radiculaire. Recherche de methodes d'estimation ayant une signification functionnelle. In: V. Gianinazzi-Pearson and S. Gianinazzi [EDS.]. Physiological and genetic aspects of Mycorrhizae. Paris, France: INRA Press. p. 217-221. (in French)

van deR Heidden, M. G. A. 2004. Arbuscular mycorrhizal fungi as support systems for seedling establishment in grassland. Ecology Letters 7:293-303.

van der Heidden, M. G. A., J. N. Klironomos, M. Ursic, P. Moutoglis, R. Streitwolf-Engel, T. Boller, A. Wiemken, and I. R. Sanders. 1998. Mycorrhizal fungal diversity determines plant biodiversity, ecosystem variability and productivity. Nature 396:69-72.

van der Heidden, M. G. A., R. Streitwolf-Engel, R. Riedl, S. Siegrist, A. Neudecker, K. Ineichen, T. Boller, A. Wiemken, and I. R. Sanders. 2006. The mycorrhizal contribution to plant productivity, plant nutrition and soil structure in experimental grassland. New Phytologist 172:739-752.

Wallace, C. S., and S. R. Szarek. 1981. Ecophysiological studies of Sonoran desert plants. VII. Photosynthetic gas exchange of winter ephemerals from sun and shade environments. Oecologia 51:57-61.

Wang, X., J. Jiang, J. Q. LeI, W. Zhang, and Y. Qian. 2003. The distribution of ephemeral vegetation on the longitudinal dune surface and its stabilization significance in the Gurbantunggut Desert. Acta Geographica Sinica 58:598-605.

Wang, X. Q., J. Jiang, J. Q. Lel, And C. J. Zhao. 2004. Relationship between spring ephemeral plants distribution and soil moisture on longitudinal dune surface in Gurbantunggut desert. Chinese Journal of Applied Ecology 15:556-560.

Wang, X. Q., J. Jiang, Y. C. Wang, W. L. Luo, C. W. Song, and J. J. Chen. 2006. Responses of ephemeral plant germination and growth to water and heat conditions in the southern part of Gurbantunggut Desert. Chinese Science Bulletin 51:110-116.

Wang, X. Q., Y. M. Zhang, J. Jiang, W. K. Yang, H. X. Guo, and Y. F. Hu. 2009. Effects of spring-summer grazing on longitudinal dune surface in southern Gurbantunggut Desert. Journal of Geographical Sciences 19:299-308.

WARD, D. B. L. 1994. The overriding influence of flash floods on species-area curves in ephemeral Negev Desert pools: a consideration of the value of island biogeography theory. Journal of Biogeography 21:595-603.

ZнAng, L. 1985. A preliminary study on the ephemerals in the Mosowan district, Xinjiang. Acta Phytoecologica and Geobotanica Sinica 9:213-222.

ZHANG, L. 2002. Ephemeral plants in Xinjiang (III): significance of community and resources. Plants 1:4-5.

Zhang, L., and C. Chen. 2002. On the general characteristics of plant diversity of Gurbantunggut sandy desert. Acta Ecologica Sinica 22:1923-1932.

Zhang, L., S. Liu, X. Zhou, and Q. Huang. 1998. The affection of engineering action on the vegetation in the Gurbantongut Desert. Arid Zone Research 15:16-21.

Zhang, T., C. Tian, Y. Sun, and G. Feng. 2006. Soil seed banks of ephemerals in the Gurbantunggut Desert. Arid Land Geography 29:675-680. 